\title{
Visible Results, Invisible Factors: Impact of Socio-economic Factors on Improving English Language Achievement in Sri Lankan Schools
}

\author{
Dr MASP Manchanayaka ${ }^{1}$ (Corresponding Author) \\ ${ }^{1}$ AHEAD-SL-CELL, Saegis Campus, Nugegoda, Sri Lanka \\ E-mail: dr.manchanayaka@saegis.ac.lk \\ Dr H Palihakkara ${ }^{2}$, Dr S Fernando ${ }^{3}$, TB Jeganathan ${ }^{4}$, \\ HKL Chamalika $^{5}$, MDMK Gunaratne ${ }^{6}$ and MAT Michael ${ }^{7}$ \\ ${ }^{2-7}$ AHEAD-SL-CELL, Saegis Campus, Nugegoda, Sri Lanka
}

Received: July 15, 2021

Accepted: Sep. 17, $2021 \quad$ Published: November 1, 2021

doi:10.5296/jse.v11i4.19012 URL: https://doi.org/10.5296/jse.v11i4.19012

\begin{abstract}
This paper presents the findings of a study that investigated the nexus between the parental level of education and the level of the English language achievement at the Ordinary Level $(\mathrm{O} /$ Level) Examination. Determining how socio-economic factors affect the achievement level of English, exploring what socio-economic factors affect the achievement of the English language, and identifying the primary socio-economic factors were the objectives. A non-experimental cross-sectional research design was used in conducting the study. The sample consisted of 291 volunteer participants from six schools in the western province. We administered a research-team designed Likert scale type questionnaire to gather the data. The instrument was pilot-tested with 74 participants. In a statistical approach to data analysis, a regression analysis was run in SPSS (version 26). Findings showed that the English language proficiency of the participants increased by 0.691 for each education level of the father, and it was increased by 0.789 for each education level of the mother. Equitable teaching of the English language, availing more time and classwork to improve the achievement levels of the English language, and using quality inputs to give more support to the students who receive lower grades were suggested as part of recommendations.
\end{abstract}

Keywords: English, factors, relationship, socio-economic, standards. 


\section{Introduction}

Sri Lanka has achieved much in terms of the provision of primary education to its school student population. School education is a state-funded function, and the country has been recognized for the achievement of equality in educational opportunities; the enrolment in school education has increased, and almost every child is in school as new educational reforms recognize that no child is left behind; the country wants to achieve universal primary education.

However, a perennial issue exists in the pass rate of the achievement of the English language - the pass rate of English at public examinations is far below compared with the achievement levels of other subjects. Over the years, research has been conducted to explore this issue, and empirical research has given insight into root causes; several socio-economic factors, for example, impact the desired and expected levels of achievement of English language proficiency. The socio-economic factors that determine students' achievement levels of English include parental employment, education, and income, and these factors relate to and influence one another; they have a causal effect, and those who have been caught in the vicious cycle of poverty tend to achieve far below the national levels of achievement in education. Schools should prepare students to secure rewarding careers once they leave school and find employment. In preparing students for the world of work, our schools' role in teaching students English and helping them gain a level of proficiency in English is noteworthy because schools are expected to teach English so that students enjoy learning and use it to gain employment.

\subsection{Background}

Sri Lanka gained independence from the British rulers in 1948, and over the years, the state school system developed following the recommendations and policy decisions. Sri Lanka is moving towards a middle-income earning nation; the state expenditure on education has been increased, and attention has been drawn to improve the quality of school education. Arulanandaraja et al. (2018) has reported that the expected levels of achievement of the English language are dismal; they suggested practical intervention plans to improve the pass rate of the English language (see p. 3). Of the reforms introduced are the reforms on the improvement of the second language teaching and learning; the state spends its funds to increase the proficiency of English and the pass rate at public examinations; nevertheless, recent statistics published by the Department of Education (DoE) show that the results of English at public examinations have been below the national standards (Aturupane et al., 2011).

\subsection{Research Problem}

The underachievement of the English language at the G.C.E. O/Level Examination is an issue of national interest. Though the students' achievement of the English language at the O/Level Examination has been hailed for its success, the present attainment level has been questioned, criticized, frowned upon, and scorned. The DoE statistics show that the expected outcome of students reaching an acceptable level of proficiency is low.

The country has not achieved a high pass rate of English language as there are 
socio-economic factors that, along with other variables, impact the achievement of the English language at the $\mathrm{O} /$ Level Examination. Public funds, for example, spent on improving the quality, achievement, and strengthening the teaching of English has not returned the expected outcomes; the state has constantly been concerned about providing equal opportunities to all the school students. However, an issue related to equitable opportunities to learn English and teach needs rethinking and policy changes.

\subsection{Review of Literature}

Socio-economic factors affect the educational achievement of school children. Several studies conducted have reported academic achievement and the vicious cycle of how students from economically disadvantaged families struggle educationally. The underachievement of education and its effects have been researched. Dundar et al. (2017) concluded that "recognizing that Sri Lanka will succeed in these aspirations only if its labour force is highly educated and skilled, the government has made education a priority" (p. 2). Sarma et al. (2018) added, "that means, while access to schools has increased and socio-economic disparities in enrollment have narrowed, gaps in learning outcomes and school quality have started to widen" (p. 13).

Significantly, the achievement of the English language at the O/L Examination has been a subject of scrutiny and attracted applause; however, a closer examination of the results indicates that the teaching of English in the country has seen a decline. 2018 report published by the British Council concluded that "in the medium to longer-term, if not addressed, this could adversely affect Sri Lanka's success in developing the economy, and its ability to respond to international trade and tourism opportunities (p. 7). Intertwined with the underachievement of the English language at the public examinations are the socio-economic factors. The unequal distribution of physical resources, lack of qualified and trained teachers of English, amount of the availability of quality inputs, deferred purposes of learning English, outdated methods of teaching, class size, poor exposure to the language, family income and parental levels of education affect the achievement levels.

The issue of underachievement is not a Sri Lankan phenomenon; it is a widespread one; studies conducted outside Sri Lanka also report similar findings. Ariani and Ghafournia (2016) believed that "as students bring their attitudes, interests, and skills to the learning situation, and these beliefs and attitudes affect the opportunities for success for every student, socio-economic status and beliefs about language learning are strong factors that teachers should take into consideration for educational progress" (p. 90). Adding further, they concluded that "therefore, investigating the learners' beliefs in the context of their varying characteristics such as socio-economic status and what effect such a variable can have on a student's learning outcome is the main component of educational progress" (ibid. 90).

The issues related to the underachievement of the English language at the $\mathrm{O} /$ Level Examination have been interdisciplinary studies. KOÇ (2016) confirmed that "socio-economic status, which generally involves factors such as parental educational background, occupation and income level, is a strong predictor of student achievement" (p. 1). Kariyawasam (2018) argued that "the wider use of English in the administrative and public 
sphere created a subtle tension amongst the rural population as concerns over the encroachment of linguistic imperialism, socio-economic deprivation and political marginalization which forced its way into their daily ways of life persisted even after independence" (p. 2).

Humble and Dixon (2017) and Sylva-Laya, et al. (2020) conducted similar studies and reported a positive correlation between educational achievement and socio-economic factors. The issue of underachievement has been a controversy among academics. Their educational attainment is deficient in learning, educational trajectory and the capacity to aspire to a better future. Although they are included in schooling, material deprivation combined with socio-territorial characteristics and cultural and administrative obstacles means [sic] that this inclusion occurs in a stratified manner" (ibid. 1-20). That is the ambit of those who fall behind the expected levels of achievement of education. The purpose of education is to replace an empty mind with an open one. The moment students finish schooling, they should secure rewarding careers, or they should be able to achieve what they want in life.

From the year 1992, various programmes to improve English language learning and teaching were introduced. Such initiatives of the National Institute of Education have reached fruition with good progress, but not with total_success. For example, 'Activity-Based Oral English' was introduced in the hope that the students in lower classes may grasp the rudiments of the English language. After that, another programme, English as a Life Skill, was introduced in 2009.

After these initiatives, various programmes have been implemented. However, those initiatives have not produced the expected outcome; the results of the O/Level English language show a dismal and gradual decline of achievement levels. As reports show, the achievement levels of the English language at the O/Level Examination have been far below the national expectations. Aturupane et al. (2011) contended that "English is normally the subject in which students experience the greatest difficulty at the public examinations, with only 35 - 40 per cent of students passing at the G.C.E. O/L Examination and 25 - 30 per cent of students passing at the G.C.E. A/L Examination" (pp. 70 - 71). The achievement levels of the English language at the G.C.E. in the year 2017 has also been subjected to critical analysis as they have been below national expectations.

\section{Method}

A non-experimental cross-sectional research design was used in conducting the research. The data were collected using a research team-administered tailor-made Likert scale questionnaire. A regression analysis of the data and descriptive measures were run on the data to obtain the results.

\subsection{Aims and Objectives}

This study addresses the following research objectives to report the root causes and examine the causal relationships of the underachievement of the English language. 
1. To determine how socio-economic factors affect the achievement level of English at the $\mathrm{O} /$ Level Examination

2. To explore what socio-economic factors affect the achievement of the English language

3. To identify the most primary socio-economic factors that influence the underachievement of the English language by the students

Aims

Several practical and implementable recommendations, together with affirmative action to increase the pass rate of the English language form part of the aims and objectives of this study. Hence, this research investigation aims to propose implementable recommendations to the policymakers, stakeholders in education, and regulatory bodies.

\subsection{Research Questions}

The problem of the current study stems from the following research questions; In conducting this research study.

1. What socio-economic factors affect the low-achievement of the English language at the $\mathrm{O} /$ Level?

2. What causal effect does the socio-economic background have on the achievement levels of the English language at the $\mathrm{O} /$ Level Examination?

3. How does family income affect the achievement of the English language?

\subsection{Hypothesis}

Does the parental level of education affect the achievement level of the English language achievement?

\section{Results}

We believed that the parents' levels of education as socio-economic factors might contribute to the level of English proficiency of students. A simple linear regression test was run on the data to evaluate the statistical significance of the possible effects of the above variables.

\subsection{Education Level of Father and Student's Performance}

A Durbin-Watson test was conducted to check for the assumption of autocorrelation in the residuals from the regression analysis and assess the relationship between variables $(\mathrm{R}=$ $0.567, \mathrm{R}^{2}=0.322$ ).

The ANOVA test results show that overall, the regression model statistically and significantly predicts the outcome variable, father's education level on the achievement level of English proficiency of students at $p<0.05(F(1,266)=126.221, p=0.000)$. 
Table 1. Model Summary

\begin{tabular}{lrrrr}
\hline Model & R & R Square & $\begin{array}{c}\text { Adjusted R } \\
\text { Square }\end{array}$ & $\begin{array}{l}\text { Std. Error of } \\
\text { the Estimate }\end{array}$ \\
\hline 1 & $.567^{\mathrm{a}}$ & .322 & .319 & 1.132 \\
\hline
\end{tabular}

Table 2. ANOVA

\begin{tabular}{|c|c|c|c|c|c|c|}
\hline Model & & Sum of Squares & $\mathrm{df}$ & Mean Square & $\mathrm{F}$ & Sig. \\
\hline \multirow[t]{3}{*}{1} & Regression & 161.732 & 1 & 161.732 & 126.221 & $.000^{\mathrm{b}}$ \\
\hline & Residual & 340.836 & 266 & 1.281 & & \\
\hline & Total & 502.567 & 267 & & & \\
\hline
\end{tabular}

Table 3. Coefficient

\begin{tabular}{|c|c|c|c|c|c|c|}
\hline & \multirow[t]{2}{*}{ Model } & Unstandardi & Coefficients & $\begin{array}{l}\text { Standardized } \\
\text { Coefficients } \\
\end{array}$ & \multirow[b]{2}{*}{$\mathrm{t}$} & \multirow[b]{2}{*}{ Sig. } \\
\hline & & $\mathrm{B}$ & Std. Error & Beta & & \\
\hline \multirow[t]{2}{*}{1} & $($ Constant $)$ & 5.000 & & & 19.486 & .000 \\
\hline & Education Level of Father & -.691 & & -.567 & -11.235 & .000 \\
\hline
\end{tabular}

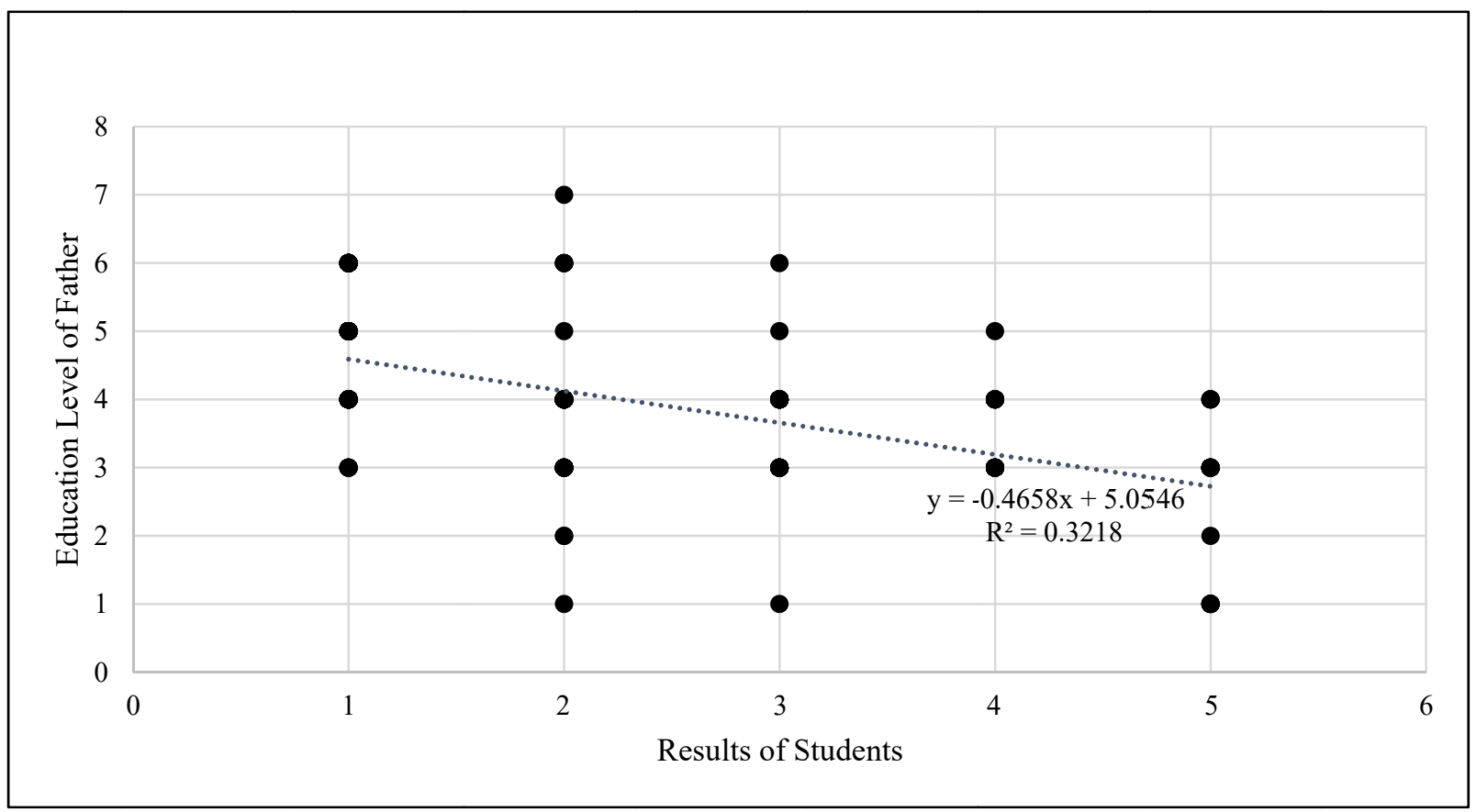

Figure 1. Scatter Plot for Education Level of Father and Results of Students 
3.2 Education Level of Mother and Student's Performance

A Durbin-Watson test was conducted to examine the autocorrelation assumption in the residuals from the regression analysis and assess the relationship between variables $(\mathrm{R}=$ $\left.0.611, \mathrm{R}^{2}=0.373\right)$.

The ANOVA test results in table 4 show that the regression model statistically and significantly predicts the outcome of the variable mother's education level on the level of English proficiency of students at the $\mathrm{p}<0.05(F(1,268)=189.317, p=0.000)$.

Table 4. Model Summary

\begin{tabular}{lrrrrr}
\hline & & & & & \multicolumn{2}{c}{ Sitd. Error of the } \\
Model & R & & R Square & Adjusted R Square & \multicolumn{2}{c}{ Estimate } \\
\hline 1 & & $.611^{\mathrm{a}}$ & .373 & .371 & 1.089 \\
\hline
\end{tabular}

Table 5. ANOVA

\begin{tabular}{ccccccc}
\hline & Model & Sum of Squares & Df & Mean Square & F & Sig. \\
\hline \multirow{2}{*}{1} & Regression & 189.317 & 1 & 189.317 & 159.600 & .000 \\
\cline { 2 - 7 } & Residual & 317.901 & 268 & 1.186 & & \\
\cline { 2 - 7 } & Total & 507.219 & 269 & & & \\
\hline
\end{tabular}

Table 6. Coefficient

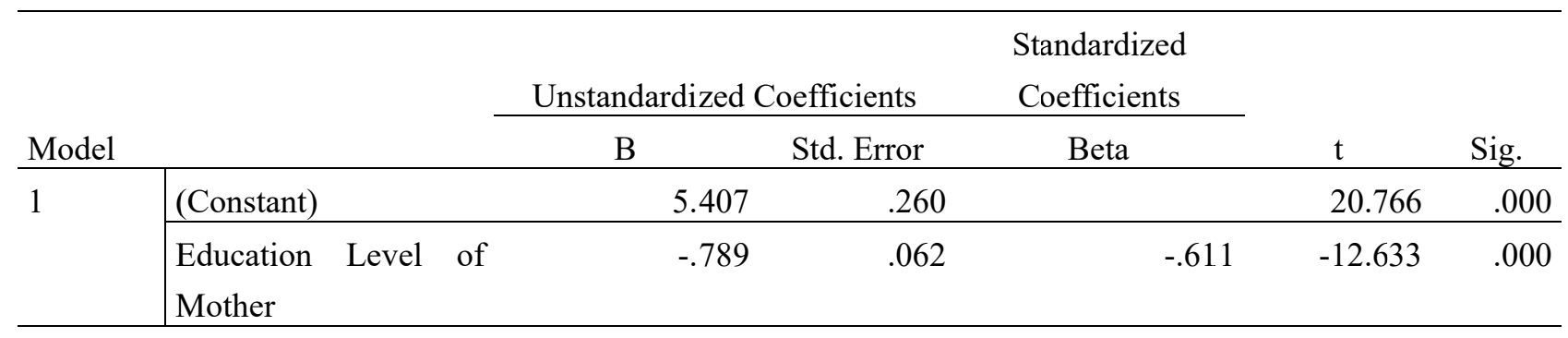




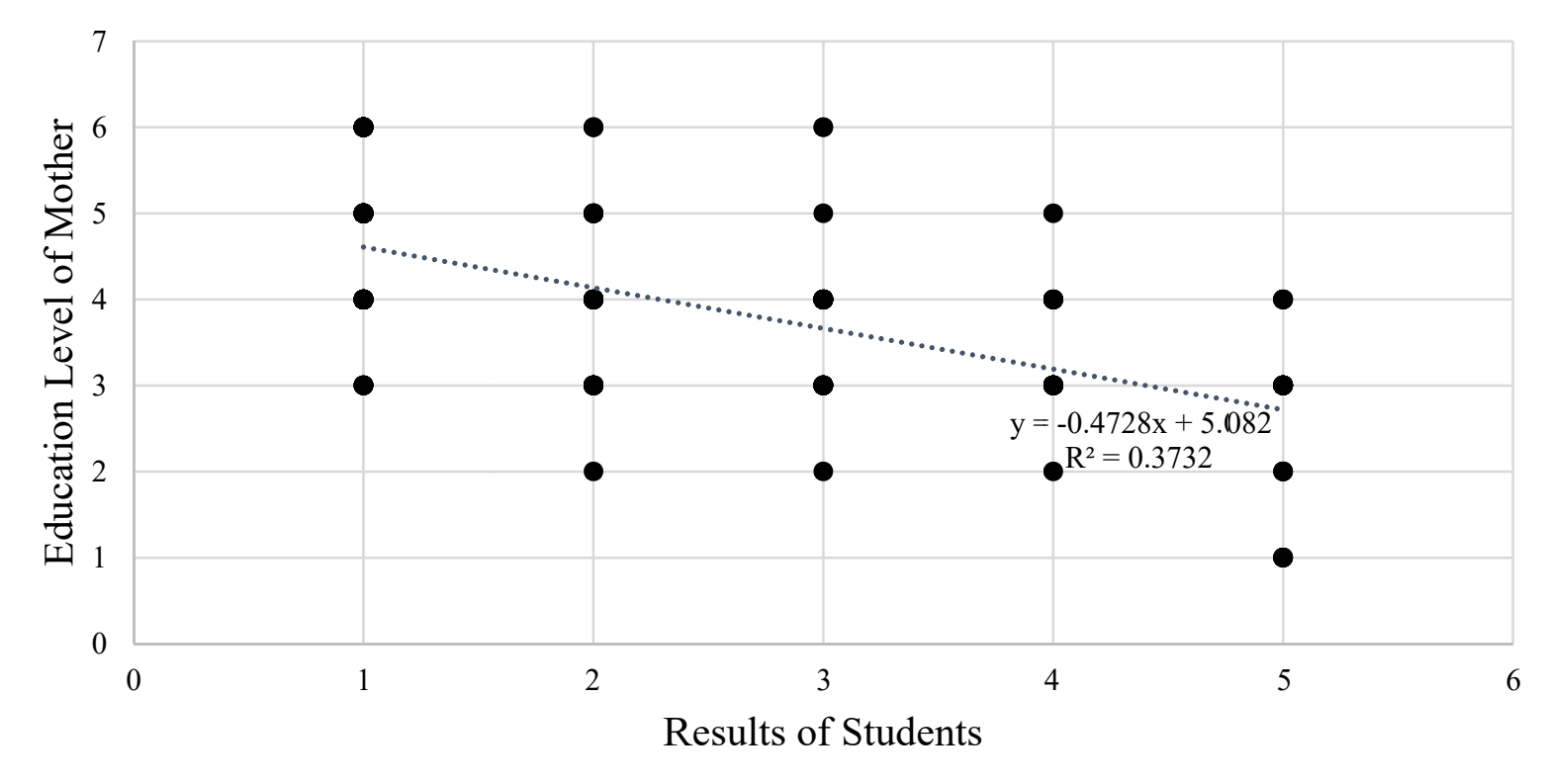

Figure 2. Scatter Plot for Education Level of Mother and Results of Students

\section{Discussion}

A simple linear regression was calculated to infer the English proficiency of students based on their father's education level. A significant regression equation was found $(\mathrm{F}(1,266)=$ 126.221, $\mathrm{p}<0.000$ ), with an R2 of 0.322. The participant's predicted English result is equal to $5+(-0.691)$ (father's education level) when the student's result is measured in A, B, C, S, and $\mathrm{W}$ passes. The participant's English proficiency increased by 0.691 for each education level of the father. Another simple linear regression was calculated to infer the English language proficiency of students based on their mother's education level. A significant regression equation was found $(\mathrm{F}(1,268)=189.317, \mathrm{p}<0.000)$, with an $\mathrm{R}^{2}$ of 0.373 . The participant's predicted English result equals $5.407+(-0.789)$ (mother's education level) when the student's result is measured in A, B, C, S and W pass. The participants English proficiency increased by -0.789 for each education level of the mother.

Previous studies conducted reported similar findings based on critical theory. Palihakkara and Silva (2020) concluded that the "philosophy of this research study was based on the postmodernism perspective of the critical theory which argues that socio-economic background of the individuals will affect the socio-economic outcomes of the society" (p.2). Little's (2011) article too concluded emphasizing the effects of socio-economic conditions under which Sri Lanka's education is in operation and the role of political and bureaucratic decisions on educational achievement and development.

\section{Limitations and Future Directions}

There are additional considerations when interpreting the results of previous research studies and planning for further studies of this nature. A lack of control groups and a small sample 
have contributed to low statistical power and limited generalizability of the results of this study. Hence, we suggest conducting further research with a large sample of students and control groups to achieve increased generalizability of results.

\section{Conclusion}

This paper presented the findings of a non-experimental and cross-sectional research study that explored the impact of socio-economic variables on the achievement of the English language at the $\mathrm{O} /$ Level Examination. These proximal factors were selected for this study due to the hypothesized strong correlation with resilient behaviours and due to the high proximal nature of the parents to their children's academic achievement.

Author Note

Disclosure

The authors declared no potential conflicts of interest concerning the research, authorship, and publication of this article.

\section{Acknowledgement}

This research was supported by the Accelerating Higher Education Expansion and Development (AHEAD) grant in co-operation with the Ministry of Higher Education of Sri Lanka funded by the World Bank.

\section{References}

Ariani, M. G., \& Ghafournia, N. (2016). The relationship between socio-economic status, general language learning outcome, and beliefs about language learning. International Education Studies, 9(2), 90. https://doi.org/10.5539/ies.v9n2p89

Arulanandaraja, S., Keppetiwalana, K. W., Handunhewa, D. S., Gunawardana, C. R., Ranasinghe, T., \& Sewwandi, O. M. (2018). G.C.E. (O/L) Examination 2018 - Evaluation Report. Department of Education. Colombo: The Department of Education - Sri Lanka. Retrieved March 3, 2021, from www.doenets.lk

Guerrero, I., Gaye, D., Rutkowski, M., \& Aturupane, H. (2011). Transforming school education in Sri Lanka. Colombo: The World Bank Group. Retrieved February 24, 2021, from www.worldbank.org

Halil, D., Millot, B., Riboud, M., Shojo, M., Aturupane, H., Goyal, S., \& Raju, D. (2017). Sri Lanka education sector assessment: Achievements, challenges and policy options. Washington: World Bank Group. Retrieved February 22, 2021, from www.worldbank.org

Humble, S., \& Dixon, P. (2017). The effects of schooling, family and poverty on children's attainment, potential and confidence--Evidence from Kinodoni, Dar es Salaam, Tanzania. International Journal of Educational Research, 95. https://doi.org/10.1016/j.ijer.2017.03.001 
Jayaratne, G., Wijeratne, S. U., Medagama, R. S., Wehella, M. M., \& Balasooriya, J. (2013). Education first Sri Lanka. Colombo: Ministry of Education. Retrieved February 12, 2021, from www.moe.gov.lk

Kariyawasam, N. P. (2018). English language education in Sri Lanka link with the learners' motivational factors. Humanizing Language Teaching(4), 2. Retrieved February 25, 2021, from www.hltmag.co.uk

Koc, D. K. (2016). The effects of socioeconomic status on prospective English language teachers' academic achievement. Navitas Royal: Research on Youth and Language, 10(2), 1. Retrieved January 21, 2021, from www.eric.ed.gov

Little, A. W. (2011). Education policy reform in Sri Lanka: The double-edged sword of

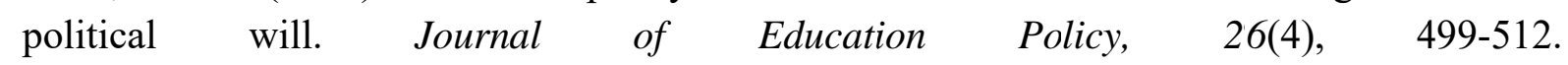
https://doi.org/10.1080/02680939.2011.555005

Palihakkara, H., \& Silva, V. D. (2020). Impact of socio-economic factors on improving English language standards in Sri Lankan schools. Canadian Centre of Science and Education, 13(12), 2. https://doi.org/10.5539/elt.v13n12p43

Sarma, V., Licht, S., \& Kalugalagedara, T. (2018). Educational inequalities in Sri Lanka: National data and local perspectives on access, quality and learning outcomes. CEPA Journal(10), 13. Retrieved February 13, 20, from www.cepa.1k

Shepherd, E., \& Victoria, A. (2018). An evaluation of English language capability. Colombo: British Council. Retrieved February 23, 2021, from www.britishcouncil.org

Sylva-Laya, M., D'Angelo, N., Garcia, E., Zuniga, L., \& Fernandez, T. (2020). Urban poverty and education. A systematic literature review. Educational Research Review, 29, 1-20. https://doi.org/10.1016/j.edurev.2019.05.002 